\title{
Nyawer as a Unique Local Tradition at School Graduation Events in Indonesia
}

\author{
Desvian Bandarsyah ${ }^{{ }^{*}}$ and Jumardi ${ }^{1}$ \\ ${ }^{1}$ History Education Study Program, Universitas Muhammadiyah Prof. Dr. Hamka,Jakarta Indonesia \\ *Corresponding author: desvian_bandarsyah@uhamka.ac.id
}

\begin{abstract}
The current school graduation ceremony has positive and negative meanings after the emergence of the "Nyawer" tradition with dangdut music entertainment instruments. This fact becomes an interesting public debate, considering that sexuality, morality and religion are the main references in the public debate. Certain indigenous groups consider this a religious or spiritual practice in the modern era. In contrast, the perpetrators (students) of the still young tradition are considered immoral conservation and exploitation. By exploring various community groups' perceptions, this article explains the culture of nyawer at school children's graduation, which is considered a unique tradition in Cibogo village, Tangerang, Indonesia. This study was conducted by interviewing teachers and principals. This article shows that the nyawer tradition is interpreted as a negative or immoral tradition by most of the community, furthermore for Islamic-based running schools. However, this unique tradition gives the meaning of happiness for students who graduate from school. The limitation of school graduation activities by organizing the nyawer dance is recommended for school stakeholders.
\end{abstract}

Keywords:

graduation tradition event; nyawer; local tradition

Article Received: 18 October 2020, Revised: 3 November 2020, Accepted: 24 December 2020

\section{INTRODUCTION}

Culture has long been a part of the fabric of human life in the socio-cultural sphere (Cohen, 2001; MacLeod \& Durrheim, 2002). Humans give birth to, create, grow and develop culture: there is no man without culture, and conversely there is no culture without man; there is no society without culture, there is no culture without society (Fuchs, 2020). Life experiences have formed boundaries, definitions, and theories about his life activities, which then gave birth to various traditions. Tradition is part of the culture that is still an exciting topic in sociology (Fenske \& Norkunas, 2017). However, this topic continues to evolve, along with the complexity of human activities. Here, we present one of the unique habitual practices of students in Indonesia which have become a new tradition.

The tradition of graduation has shifted meaning and purpose to become a mandatory tradition in schools in Indonesia. Surprisingly, the graduation ceremony was performed by inviting the dangdut dance in junior high school graduates' tradition. This is interesting because generally, the graduation ceremony is done formally. Although there are several entertainment events, they are limited to complementing the ceremony such as the orchestra, traditional art music, and student performances. Currently, dangdut music currently prevalent in the general public has entered the world of child education. Generally, dangdut music is used for weddings, childbirth, community salvation, and regional celebration parties (Dunbar-Hall, 2013; Toomistu, 2019). This is a new tradition for education, which has shifted its meaning to become a traditional ceremony (Sutopo et al., 2017).

In anthropology, customs are religiously magical habits of an indigenous population that include corresponding cultural values, norms, laws and regulations (Seneviratne, 2008; Weintraub, 2006). This then becomes a system or regulation that has been established and includes all conceptions of human cultural systems in 
social life (Ariyono, 1985). In America, the tradition of separation is known as the prom night" (Prettyman, 2004). Prom night comes from the word Promenade, which means a formal meeting where guests walk around a room and get to know each other (Arroyo et al., 2019). The term prom night began in 1920 to teach students to behave as respectable men and women according to gender and race, usually filled with various events including musical performances and dancing. (Chamely-Wiik et al., 2019). This event requires attendees to wear formal or formal clothes. Men wear suits and women wear dresses (Casement, 2011).

In 1950, prom night was growing and was known and even adopted by the younger generation from other countries (History.com, 2018; Prettyman, 2004). However, the prom night event caused controversy because of the different skin tones (Castle Bell \& Harris, 2017). Some countries have graduation traditions done to the extreme, such as drinking alcohol and so on. Prom night is a tradition in the United States that has been adapted by final year students in several schools in Indonesia. Prom nights in other countries are farewell nights where we all enjoy dinner together, have a dance party, and spend a farewell evening together. Prom night is not an art performance, but a farewell night. Therefore, the attendance of all students and even teachers must be considered. A good event, unique themes, and luxurious decorations will be meaningless if the farewell event's goal and an atmosphere of togetherness for all students is not achieved (Davis, 2004). Form a prom night committee that can accommodate the aspirations of all students.

Prom night events in Indonesia lead to an understanding of freedom that transcends boundaries. Several cities have noted that graduation celebrations have been conducted inappropriately, leading to criminal and immoral acts (Nurish, 2010). Splash After class, a bikini summer dress party, the event was held in the swimming pool at one of the star hotels in Central Jakarta. This is contrary to the eastern culture, which still prevails in Indonesia. Generally, the tradition of graduation in Indonesia is carried out with crossing out uniforms with markers or paint (Hamdi et al., 2015). Scribbling fences, convoys and group photos. They do this activity with various motivations, such as expressing joy, freedom, life experiences, peer influence, and solidarity forms. Almost all levels of high school do the same thing (Smith, 2014).

Interestingly, it does not appear that pesantren graduates do this. Differences in graduation traditions in Indonesia and other countries are based on local culture and customs. Indonesia has many cultures, customs, including arts in each region (Halim, 2018). The diversity of national languages and cultures is recorded that more than 700 local languages exist with various dialectics of various ethnic groups (Widodo, 2016). This diversity also affects the tradition of graduating from school students in Indonesia (Marcellino, 2008).

One of the traditions of graduation in Indonesia is religious lectures by doing sawer or nyawer. Nyawer is a cultural practice in Java with long accompanied wedding celebrations and circumcision to accompany the rhythm of dangdut or jaipong music (Baders, 2011). The nyawer is currently featured on various events with the giving of money or anything of value to a singer or artist for free $(K B B I, 2000)$. Nyawer is usually found at dangdut music events which are held at wedding ceremonies, circumcisions or democratic parties using a stage. The meeting of singers, dancers and audiences is an intracorporeal relationship that forms interactions and diverse perceptions in society and academia. (Bader \& Martin-Iverson, 2014). Not a few of these events bring in national artists who are well known to the public.

The chant of the music that was played invites the invitees to join in the fun together. Excitement is expressed by giving the artist 
money as a form of appreciation or just giving a tip (a gift or a sum of money) (Delmar, 2019; Webley \& Wilson, 2010). This tipping activity is sometimes seen as unfavourable, because it can be given by touching certain parts of the artist's body. The Nyawer community calls the charitable activity. One of the Islamic private elementary schools located in Tangerang Regency, West Java, Indonesia has an interesting tradition of celebrating student graduation and class promotion. Graduation and class promotion are celebrated by holding arts and religious stages. The exciting thing about this activity was that each student appeared on stage to read the holy Qur'an or recite a hadith. Each participant is given no more than five minutes to appear on stage to hone each student's creativity in showing their best.

In each performance, the nyawer tradition is carried out by the students' parents/guardians by throwing money or sprinkling it on the committee's stage. (Seneviratne, 2008). Nyawer is performed by the community when a music party is held. The school has been anticipating how to change the tradition of sawer from negative to positive things, one of which is by doing nyawer, when their children appear on the stage during graduation or class promotion.

This study aims to gather views of the Nyawer culture at the school farewell ceremony. For this reason, in this research, the following questions were made:

1. What are the principal, teachers, students, and parents of students about the graduation ceremony and class promotion?

2. What are the reasons for the promotion and graduation event for the graduation ceremony?

3. What is the community's view of nyawer activities for school children?

\section{METHOD}

In this study, understanding nyawer activities' meaning is explored as a traditional folk dance variation tradition performed by students at the graduation ceremony. To reveal how social changes and cultural dynamics enter the world of education, especially elementary school children. The intersubjective perspective is the primary tool used to examine work (Boyer, 2018). This research uses qualitative methods with a case study approach. We conducted open interviews with principals, teachers, students and parents. Data collection techniques were carried out by means of interviews and observations. The results of the interviews were recorded, then data triangulation was carried out for further analysis.

\section{RESULTS AND DISCUSSION}

\section{Nyawer as a Graduation Cultural Practice}

A school graduation day is an event that is very impressed for all students and is also a time that has been waiting for after completing the national exam activities, especially if the muchawaited announcement is really what is expected, they pass with grades that can be proud of. When the school graduation announcement is like it is a tradition, students celebrate it with the nyawer tradition. Nyawer is a Javanese and Sundanese tradition, where singers are paid a salary by the people who employ them. For some students, this seems to be a tradition that cannot be abandoned and may even have to be passed on. Perhaps also for them, it is a symbol of the completion of formal education in abandoned schools.

The concept of nyawer as a graduation culture is similar to the context of dance performances, nyawer involves handing over money to female performers (Bader \& Richter, 2014). The difference is in terms of graduation in a private Islamic primary school, the students who graduate prepared for their best appearance and attract them on the stage. Aim to get lots of saweran money. The show displayed is related to Islam, such as; murotal al quran, memorizing Al Quran, dai, qosidah etc. When saweran is performed during a life cycle celebration, the 
audience often goes up on stage to put down their saweran money. As such, the audience is expected to hand over money (nyawer) to the players at some point during the show (Zakaria, 2014).

It is clear that people were involved in the show for many reasons. Most of the people who give money to players think of it as a tribute to the player. Some of them were of the view that this host would host them. Some presenters feel obliged to appear on stage if the host is a family member or close friend. Conversely, those who are not invited will feel "embarrassment" (shame) when they are unable to do the same. These are the students who graduate.

\section{Islamic Primary School Moral Values}

Islamic elementary schools are schools that provide religion-based education. Cibogo Village, Regency only has three public elementary schools (SDN) and one private religion-based school. Islamic elementary schools are alternative schools of choice for parents in providing a balanced education between world science and the afterlife (religion). Until 2020, the existence of Islamic elementary schools can realize the dreams of parents of students to produce graduates who have sufficient religious and scientific abilities with the hope of producing a wise and wise generation to continue the baton of the nation's struggle and seeing the reality today that the quality of Indonesian education is still below. Leaders are not mandated, corruption, collusion, and nepotism are still rampant, making religious-based schools a solution to the chaos of life. Nurhadi (2018) explained that, since the last thirty years, religionbased private schools have tended to be more and more in demand starting from this early to high school level. Apart from urban and semi-urban communities, this trend has also begun to penetrate rural areas, which are synonymous with strong families and relatives in individual decision-making.

Environmental observations in one of the
Islamic elementary schools like Madrasah Ibtidaiyah (MI) Nurul Ilmi in Cibogo Village, Tangerang Regency, can be stated Cibogo Village community has a high level of understanding of religion. This can be proven by registering new students from kindergarten to elementary school level, choosing Islamic primary schools over public primary schools to provide education for their children. Parents' awareness in choosing Islamic primary schools is inseparable from the large amount of information that children can easily obtain through current technology. In addition, the choice to MI Nurul Iman is due to the very cheap cost of education, making it easier for parents (Nurhadi, 2018), especially for the middle to lower class. The cost factor also determines the enrollment rate of new students (Asadullaha, 2018).

Education and religion are a must to strengthen the character of students in living wisely (Ainiyah, 2013). Permendiknas No. 22 of 2006, explains that Islamic religious education is expected to produce humans who always strive to perfect faith, piety, and have a noble character, noble morals including ethics, character, or morals as a manifestation of education. Education provides thought to understand how prepared we are to face the technological era, while religion regulates human life, both humans and creatures. How then education and religion can coexist well in the state and nation's life, a suitable formulation is needed. The role of education and religion in Indonesian society is very important. This is also the basis for the growth of religion-based education, especially in Cibogo Village.

Religion-based education is now an option for ordinary and middle-class people (Rohinah, 2014). Religion-based education is preferred for several reasons including first, awareness of the importance of religious knowledge for every child in a family; second, the education of a family head is getting better; and third, in terms of the social environment in society with widespread promiscuity such as drug cases and illegal drugs 
can make a family head choose religion-based education (Nurish, 2010). Asadullah (2018) conveyed in his research that in Indonesia from 2009 to 2016, the levels of early childhood education (PAUD) and elementary school (SD) contributed the largest increase to be the largest contributor to the increase in the choice of religion-based private schools. Data from the Ministry of Education and Culture shows that at the national level, during the number of public primary schools from 2009 to 2016, which amounted to $0.41 \%$, the number of private primary schools increased $25.91 \%$. The MI curriculum is the same as the elementary school curriculum, it's just that MI has a larger portion of Islamic education. Besides teaching subjects like elementary school, it is also added with subjects such as Al Qur'an, Hadith, Aqidah Akhlaq, fiqh, Islamic Cultural History, and Arabic. Madrasah as an educational institution is a place that fulfils institutional elements which are not the case in other educational institutions (Hamdi et al., 2015). The duties carried out by madrasas at least reflect that of other Islamic educational institutions. This proves that there is public awareness to improve the nation's morals, which is felt to be starting to decline with the large number of student enrollments in religion-based schools.

Madrasah Ibtidaiyah is a more modern Islamic Elementary Education Institute, which combines Islamic boarding schools and Islamic boarding schools that integrate religious knowledge and general knowledge. Madrasas as Islamic educational institutions function to connect the old system and the new system by maintaining old values that are still good can be maintained and take something new in science, technology, and economics that is beneficial to the lives of the people, while the content of the madrasah curriculum is generally the same with education in pesantren coupled with general sciences (Halim, 2018). With Madrasah Ibtidaiyah education, everything will be realistic, and it is possible to be realized so that education provides many positive impacts on the journey of human life so that everyone needs education.

\section{The Academic Discourse of Nyawer Graduation Traditions}

According to Abraham H. Maslow and Carl R. Rogers, if you look at the humanistic psychological theory, it is said that human behaviour is determined by himself and not by environmental conditions or knowledge. Students who carry out the nyawer graduation tradition mean those who still preserve the culture around them. In addition, the nyawer tradition shows that they have a caring character for culture because the students show their pride in the nyawer tradition by doing positive, not negative things. However, all of this can be instilled in students and educators continue to remind and invite their students to preserve Indonesian indigenous culture, including the tradition of nyawer graduates (Sutopo et al., 2017).

Meanwhile, according to the Sundanese dictionary, nyawer or sawer is divided into two definitions; 1) Sawer is asking the audience for money and turning into a nyawer which means spreading from happiness, money, and advice; 2) Sawer (nyawer), sowing (bride) with rice mixed with tektek money (betel folds) and sliced turmeric. From this understanding, sawer is a sacred incident that spreads during the graduation tradition of one of the private elementary schools in Tangerang Regency. Packaged with interesting and useful events, namely reading the Al Quran, Hadiths, memorizing dai letters. It can brings benefits both from the academic and spiritual side of the students. Apart from getting saweran money, showing talent, competing, they also get a reward for having "fastabiqul khoirot".

\section{The motivation of Participants to Engage in} Nyawer

The stigma of the pious meets in the tradition of Nyawer graduation practice. Students 
engage in nyawer meetings when students drop the sixth grade or move up to a higher level (Jeremy, 2008). On the other hand, the students mentioned that a nyawer encounter could be a competition between speakers to get the performer's attention. This implies increasing, not letting go, tension but also competition. Bajidoran dance describes how a participant in the audience (bajidor, the equivalent of a presenter in a dangdut show) gets on stage holding hands more than just money for a female player Caturwati, (2006). Competition among participants triggers their desire to attract the attention of the performers. Some men become so enthusiastic that they waste money. On several occasions, they threw rupiah bills into the air over a performer and dancer. While there may be several interrelated reasons for doing this, female artists say that these people sometimes have personal interests and jealousy arises when other artists catch the artist's attention. Female artists are always aware of these situations, considering that they can often lead to quarrels and sometimes even fights between performers (Bader, 2011). Unlike the Nyawer tradition of graduation, the incidence of fights will be minimal because it is wrapped in Islamic values, and hopes to get blessings from the one and only God. In addition, they are increasing faith with the existence of memorization, knowledge of the Qur'an and hadith.

Wawan (a pseudonym), an audience member, said that some of the audience who attended the event had urged him to ask. Interestingly, they cheerfully greeted graduations or performances at private Islamic schools. We observed female participants of all ages actively participating as presenters. Cheer 'again and again' for a boost or some cloak to keep playing. They sometimes do not realize that the money given is more than what was prepared. Asih (pseudonym) said, 'I only want to spend around 20,000 or 30,000 for various reasons including the participants' family, friends and indeed their appearance is stunning. Nevertheless, some residents spend their money just for fun.

Based on the research results, it is proven that students are involved in the Nyawer graduation tradition for various reasons. Some authors emphasize feelings of pride, competition between speakers to attract students' attention, for male audiences, there may be a negotiation of masculine identities. The audience claims that they enjoy the stage show. The primary purpose of being involved in the meeting's answer is to show gratitude to one God.

\section{The local tradition of nyawer (sawer) in elementary schools}

Students who attend private Islamic primary schools are taught to keep the class clean because it is part of their faith. Every student who wears footwear must remove his footwear before entering the classroom. Students are also allowed to use sandals for school. This simplicity is instilled in all students with the hope of growing a soul that remains "tawadhu" or humble so that it grows into a "mutawadhi", that is, someone who grows in himself the humility and height solely of his faith in Allah SWT.

Islamic private primary schools have continued to survive in the midst of other private educational institutions' birth with better concepts. In private Islamic primary schools, students are educated with simplicity and clarity in studying so that students who graduate from private Islamic primary schools have a strong character, namely sincere in learning and open to all progress. Character education that is most appropriate to be applied as a whole is at the age of basic education, where the age of primary education is the golden age in shaping a person's character, character and personality (Sutopo et al., 2017). This character continues to be instilled by the teacher and principal in each of his students (Patimah, 2015).

One of the Islamic private elementary schools in Tangerang Regency has a unique local tradition at the end of each school year. This 
unique local tradition is often referred to as sawer. This activity was carried out during the class separation and class promotion. Held at night, in open fields by renting vacant land, renting a sound system and setting up stages and tents. The activity was attended by parents, guardians of students, local religious leaders and local village heads. The teacher acts as the committee of the sawer tradition. Some committee members work as cashiers, which is a place to exchange money (in the form of Rp. 500, Rp. 1000) to money with a value of more than Rp. 5,000, Rp. 10,000, up to Rp. 20,000. Some committee members are also tasked with taking the money from saweran thrown at every student who appeared because humans are visual creatures like to see beauty. The sawer tradition is part of the beauty in entertaining human visualization.

Generally, sawer is usually found when attending a wedding ceremony or circumcision with dangdut music events. Sawer has various meanings and meanings. As a custom, sawer in Sundanese society is poetry and is usually used in traditional wedding ceremonies. The contents of the poetry use language easily understood and can be used as a mandate in living life because it has spiritual value (Masduki, 2015). Titin (2015) in the Third National Conference of Language and Literature, explained that the word sawer is a tradition from the ancestors of Sundanese urang from generation to generation. The sawer's content is a saying from parents to their children who will live a new life, namely getting married (Irawan, 2012).

The saying (sawer) is usually conveyed or spoken by the sawer interpreter. The contents of the sawer in the form of household guidance, religious teachings, and the teachings of manners between husband and wife "Sawer Panganten" are part of a series of ceremonial wedding ceremonies developed in the Sundanese style. Sawer panganten is a form of story sung (ditembangkeun). This Tembang sawer is full of values or life guidance concepts or advice to the bride and groom in forming a household mentality. Products of a nation in the form of culture and traditions spread in various regions in Indonesia. Culture and tradition have personality values as guidelines for mental formation. Sawer can also be interpreted as symbolic communication on the traditions of the Sundanese people. Supinah (2005) explains that sawer or nyawer comes from the word awer, meaning waterfalls were splashing. Another definition of sawer is taweuran, an activity carried out in the roof panyaweran or shower (Pien Supinah, 2005).

During the Dutch colonial period, aristocrats often invited tayub players to celebrate their celebrations. It is not uncommon for the aristocrats to show off their wealth by giving musicians and dancers money. The amount of money awarded is announced. This habit develops with the term sawer (Anik Juwariyah, 2019). Sawer has shifted meaning when performing dangdut (single organ), or tarling music. In some areas, dangdut or tarling performances are unique. In the city of Tegal, the performance of dangdut or tarling reflects the social status of the people of the city of Tegal. Not a few of these shows featured singers who had popularity. In this show, not a few viewers asked specifically for the song they liked and then gave money to the singer who performed the song. This term is known as sawer. The amount of the tip is not specified. It depends on each audience's ability, but the value given can be valued at the ability of the sawer giver.

Nyawer is giving money or anything of value to a singer or artist for free. Nyawer is asking the audience for money or the audience giving money to the player. Besides music, sawer is also known as sawer for walking children, sawer during the marriage, sawer when pregnant women (memitu tradition) (Wariin Basyar, 2014) "Nyawer" for some of the community is known as the culture of the marginalized people. Some people even think that nyawer is the culture of spending money (hedonist). The difference in the 
meaning of sawer in each event is the "prerogative" of the activity implementer. The meaning of sawer varies depending on the event being held. As in the sawer event, when a new child can walk in the Sundanese society it is called "lelengkah halu" (stepping slowly). Sawer on "lelengkah halu" using change and candy. (Wariin Basyar, 2014) Sawer is interpreted as an expression of gratitude to God Almighty for children's ability and courage to learn to walk. It is different when the sawer event is at a wedding. Sawer events at weddings use change, rice and candy. Each has a meaning, namely, prosperity, prosperity and romance. It will also be different from the sawer at the shower of pregnant women.

Sawer at graduation and grade promotion has similarities with sawer performed on tarling dangdut singers, or tayub players. The most apparent difference is only in the programs that are presented. In the tradition of graduation and grade promotion, it features students delivering short letters or hadiths on the stage, then the entire audience can throw coins of various values, or each parent can immediately go up to the stage by pouring money over the heads of their children who are performing.

On the other hand, there is a committee in charge of collecting coins, and there is a committee for changing coins for parents or people present. The nyawer tradition became more crowded when the coins were deliberately smashed into zinc sheets (a material often used by some people to replace roof tiles) which the committee deliberately provided so that the saweran money did not spread to the sides of the stage wings. At the sawer program, the farewell and class promotion program means that every child must be provided with sufficient knowledge in pursuing life. The money that is given or thrown when the child performs a speech is used for the needs of students in the coming school year and is used to pay for the stage rent and the rent for the venue for the implementation of these activities, besides that the nyawer is also a place for school promotion to the community. The school hopes that with the sawer activity, parents are more willing to sacrifice for the progress of their children in terms of education considering that Islamic elementary schools cannot be said to have a good location, given the better development of students and the interest of parents to send their children to school Religion.

\section{CONCLUSIONS}

Nyawer for some people is identical to negative habits. However, the nyawer tradition can be a festive tradition in one of the Islamic elementary schools in Cibogo, Tangerang Regency, which has its local tradition. This local tradition can be a good example, that every child has the ability, for that parents must give the best for their children in pursuing future life. These local traditions can be developed to characterize religious schools in Banten province. Apart from that, the local government's role is highly expected, both a touch of technology and the infrastructure of Islamic schools that are still in need, especially in the Tangerang Regency area to develop by being able to maintain local traditions properly.

\section{REFERENCES}

[1] Ainiyah, N. (2013). Pembentukan Karakter Melalui Pendidikan Agama Islam, Jurnal Al-Ulum. 13(1), 25-38.

[2] Anik Juwariyah. (2019). Proceedings of the International Conference on Arts and Design Education (ICADE 2018). Atlantis Press.

https://doi.org/https://doi.org/10.2991/icade $-18.2019 .33$

[3] Ariyono, A. S. (1985). Kamus Antropologi. Akademika Pressindo.

[4] Arroyo, B., Stadler, J. P., Mini, D., Strassfeld, B., \& Oeming, M. (2019). Porno Cultures Podcast: graduate student roundtable. Porn Studies, 6(4), 428-443. https://doi.org/10.1080/23268743.2019.157 
4419

[5] Asadullaha, M. dan M. N. (2018). Madrasah for girls and private school for boys? The determinants of school type choice in rural and urban Indonesia, International Journal of Educational Development. 62, 96-111.

[6] Bader, S. (2011). DANCING BODIES ON STAGE Negotiating nyawer encounters at dangdut and tarling dangdut performances in West Java. Taylor Francis Online: Indonesia and Malay World, 333-335. https://doi.org/https://doi.org/10.1080/1363 9811.2011.614085

[7] Bader, S., \& Martin-Iverson, S. (2014). Creative Intersubjectivity in Performance: Perspectives from the Asia-Pacific. Ethnomusicology Forum, 23(2), 149-162. https://doi.org/10.1080/17411912.2014.925 641

[8] Bader, S., \& Richter, M. M. (2014). Dangdut Beyond the Sex: Creating Intercorporeal Space through Nyawer Encounters in West Java, Indonesia . Ethnomusicology Forum, 23(2), 163-183. https://doi.org/10.1080/17411912.2014.926 629

[9] Baders, S. (2011). Dancing bodies on stage, negotiating nyawer encounters at dangdut and tarling dangdut performances in West Java. Indonesia and the Malay World, 39(115), 333-355. https://doi.org/10.1080/13639811.2011.614 085

[10] Boyer, R. E. (2018). Significance of a Culture Test Given to Geology Graduate Students. Journal of Geological Education, 11(2), 69-73. https://doi.org/10.5408/00221368-11.2-1.69

[11] Casement, A. (2011). Last Night of the Proms: Review of: Last Night of the Proms, Henry Wood Promenade Concerts, Royal Albert Hall, London, Saturday, September
11, 2010. Jung Journal, 5(2), 117-118. https://doi.org/10.1525/jung.2011.5.2.117

[12] Castle Bell, G., \& Harris, T. M. (2017). Exploring representations of Black masculinity and emasculation on NBC's Parenthood. Journal of International and Intercultural Communication, 10(2), 135152.

https://doi.org/10.1080/17513057.2016.114 2598

[13] Caturwati, E. (2006). Perempuan dan Ronggeng di Tatar Sunda Telaah Buku Sejarah Budaya. Pusat Kajian Lintas Budaya.

[14] Chamely-Wiik, D., Haky, J. E., Louda, D. W., Romance, N., Goode, A. B. C., \& Vitale, M. R. (2019). The effects of a university/secondary school partnership on the communication skills of STEM graduate students. International Journal of Science Education, Part B, 9(1), 72-81. https://doi.org/10.1080/21548455.2018.154 3978

[15] Cohen, B. R. (2001). Science and humanities: across two cultures and into science studies. Endeavour, 25(1), 8-12. https://doi.org/https://doi.org/10.1016/S016 0-9327(00)01335-1

[16] Davis, D. J. (2004). Book Review of Community Colleges as Cultural Texts: Qualitative Explorations of Organizational and Student Culture. Educational Studies, $36(2)$.

https://doi.org/10.1207/s15326993es3602_7

[17] Delmar, N. (2019). "What Is Bought Is Cheaper Than a Gift": The Hidden Burdens of Gifts-in-Kind and Policies to Help. Legal Reference Services Quarterly, 38(4), 197231.

https://doi.org/10.1080/0270319X.2019.169 6070

[18] Dunbar-Hall, P. (2013). Dangdut Stories: A Social and Musical History of Indonesia's Most Popular Music. Popular Music and 
Society, $\quad 36(1), \quad$ 137-139. https://doi.org/10.1080/03007766.2012.697 784

[19] Fenske, M., \& Norkunas, M. (2017). Experiencing the More-than-Human World. Narrative Culture, 4(2), 105-110. https://doi.org/10.13110/narrcult.4.2.0105

[20] Fuchs, C. (2020). Materialism and Society. In Communication and Capitalism (Vol. 15, pp. 41-68). University of Westminster Press. https://doi.org/10.2307/j.ctv12fw7t5.7

[21] Halim, W. (2018). Young Islamic preachers on Facebook: Pesantren As'adiyah and its engagement with social media. Indonesia and the Malay World, 46(134), 44-60. https://doi.org/10.1080/13639811.2018.141 6796

[22] Hamdi, S., Carnegie, P. J., \& Smith, B. J. (2015). The recovery of a non-violent identity for an Islamist pesantren in an age of terror. Australian Journal of International Affairs, 69(6), 692-710. https://doi.org/10.1080/10357718.2015.105 8339

[23] History.com. (2018). The Racist History Of Prom. 31 Agustus 2018.

[24] Irawan, C. (2012). Kontinuitas dan Perubahan Sawer Panganten dalam Upacara Perkawinan Adat Sunda Kontemporer. Journal of Urban Society's Art, 12(2), 90100.

[25] Jeremy, W. (2008). Modern Noise, Fluid Genres: Popular Music in Indonesia, 19972001. University of Wisconsin Press.

[26] KBBI (p. 1275). (2000).

[27] MacLeod, C., \& Durrheim, K. (2002). Racializing teenage pregnancy: "culture" and "tradition" in the South African scientific literature. Ethnic and Racial Studies, 25(5), 778-801. https://doi.org/10.1080/0141987022000000 268
[28] Marcellino. (2008). English language teaching in Indonesia: A continuous challenge in education and cultural diversity. TEFLIN Journal, 19, 57-69.

[29] Masduki, A. (2015). Sawer panganten As Family Life Guidance In Bandung Regency. Patanjala, 7(3), 431 - 444.

[30] Nurhadi. (2018). Pemilihan Sekolah Swasta Berbasis Agama Dalam Perspektif Angst Society, Jurnal Sosiologi Walisongo. 2(2), 203-216.

[31] Nurish, A. (2010). Women's same-sex relations in Indonesian pesantren. Gender, Technology and Development, 14(2), 267277.

https://doi.org/10.1177/0971852410014002 07

[32] Patimah. (2015). Pendidikan Karakter Di Madrasah Ibtidaiyah. Al Ibtida Jurnal Pendidikan Guru Mi, 2(1). https://doi.org/10.24235/al.ibtida.snj.v2i1.1 75

[33] Pien Supinah. (2005). Sawer: Komunikasi Simbolik pada Adat Tradisi Suku Sunda dalam Upacara Setelah Perkawina. MEDIATOR, 7(1), 87.

[34] Prettyman, S. S. (2004). Book Review of Prom Night: Youth, Schools, and Popular Culture. Educational Studies, 36(2), nullnull.

https://doi.org/10.1207/s15326993es3602_8

[35] Rohinah. (2014). Model Pembelajaran Pendidikan Agama Islam (Pai) Berbasis Multikultural Sebagai Upaya Penanaman Karakter Pada Siswa Sekolah Dasar Sanggar Anak Alam (Salam) Nitiprayan Kasihan Bantul Yogyakarta. Pendidikan Agama Islam, XI(2), 270.

[36] Seneviratne, K. (2008). Turning the Tide of Cultural Imperialism with Dangdut. Media Asia, 35(4), 225-232. https://doi.org/10.1080/01296612.2008.117 71962

[37] Smith, B. J. (2014). Sexual Desire, Piety, 
and Law in a Javanese Pesantren: Interpreting Varieties of Secret Divorce and Polygamy . Anthropological Forum, 24(3), 227-244.

https://doi.org/10.1080/00664677.2014.947 918

[38] Sutopo, O. R., Nilan, P., \& Threadgold, S. (2017). Keep the hope alive: young Indonesian musicians' views of the future. Journal of Youth Studies, 20(5), 549-564. https://doi.org/10.1080/13676261.2016.124 1871

[39] Toomistu, T. (2019). Embodied Notions of Belonging: Practices of Beauty among Waria in West Papua, Indonesia. Asian Studies Review, 43(4), 581-599. https://doi.org/10.1080/10357823.2019.165 7066

[40] Wariin Basyar, H. I. (2014). Nilai-Nilai Kearifan Lokal (Local Wisdom) Tradisi Memitu Pada Masyarakat Cirebon (Studi Masyarakat Desa Setupatok Kecamatan Mundu). Edunomic Jurnal, 2(1).

[41] Webley, P., \& Wilson, R. (2010). Social Relationships and the Unacceptability of Money as a Gift. The Journal of Social Psychology, 129(1), 85-91. https://doi.org/10.1080/00224545.1989.971 1702

[42] Weintraub, A. N. (2006). Dangdut soul:
Who are 'the people' in Indonesian popular music? Asian Journal of Communication, 16(4), 411-431. https://doi.org/10.1080/0129298060101244 4

[43] Widodo, H. P. (2016). Language policy in practice: Reframing the English language curriculum in the Indonesian secondary education sector. In English language education.

[44] Zakaria, A. (2014). Perayaan Kelulusan SMA/ SMK di Yogyakarta diwarnai Tawuran Antarpelajar. Tempo.Co. 